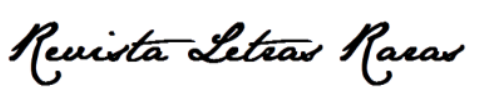

ISSN: 2317-2347 - v. 9, n. 4 (2020)

Todo o conteúdo da RLR está licenciado sob Creative Commons Atribuição 4.0 Internacional

\title{
iPractice for oral interviews: The use of technology to reduce the
} anxiety of students of Portuguese as an Additional Language

\author{
$(\mathrm{PAL}) /$ \\ Prática para entrevistas orais: 0 uso da tecnologia para reduzir \\ a ansiedade de estudantes de Português como Língua Adicional
}

$$
\text { (PLA) }
$$

\section{Eduardo Viana da Silva*}

Ph.D. in Luso-Brazilian Literature with an emphasis in Applied Linguistics from University of California, Santa Barbara (UCSB). He holds an interdisciplinary degree in teaching "Certificate in College and University Teaching" from UCSB, a TESOL (Teaching English to Speakers of Other Languages) graduate certificate from Brigham Young University (BYU), and an M.A. in Luso-Brazilian literature, also from BYU. Eduardo is associate teaching professor and coordinator of the Portuguese Program at the University of Washington, Seattle, United States. His main areas of interest are Applied Linguistics, Luso-Brazilian literature and culture, and curriculum development with a focus on culture and task-based language teaching (TBLT) and Global Citizenship. Other areas of interest include teaching languages for special purposes and the use of technology in the classroom.

(iD) https://orcid.org/0000-0002-3651-3524

Received: November, 13th, 2020. Approved: December, 21th, 2020.

How to cite this article:

VIANA DA SILVA, Eduardo. iPractice for oral interviews: The use of technology to reduce the anxiety of students of Portuguese as an Additional Language (PAL). Revista Letras Raras, Campina Grande, v. 9, n. 4, p. 11-29, dez. 2020.

\section{ABSTRACT}

This case study looks at the use of voice recording technology and its benefits in preparation for oral interviews in courses of Portuguese as an Additional Language (PAL). It focuses particularly in how the use of voice recordings can decrease the levels of anxiety in a group of students of Portuguese at the university level. We analyze the preparation process for oral interviews with 13 university students enrolled in a summer Portuguese class in a major university in the Pacific Northwest of the United States. This study provides evidence that students' performances during the faceto-face oral interviews are benefited from the practice for oral interviews using technology. It shows a possible correlation between preparation and the reduction of anxiety during the face-to-face interviews. The preparation

$\triangle$ evsilva@uw.edu 


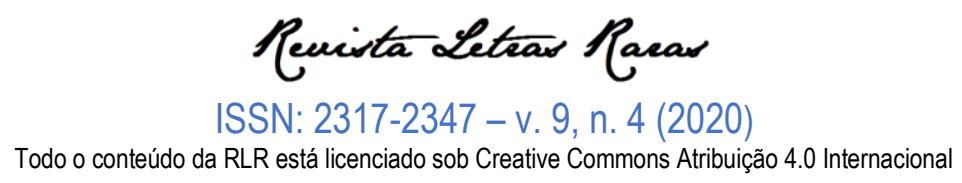

provided to this group of students also emphasizes the importance of having a systematic approach for oral interviews and the need of addressing the levels of anxiety experienced by language students during such interviews. Other studies on student anxiety are taken as the theoretical foundation for this case study, especially the seminal work by Horwitz, Horwitz and Cope (1986) with the creation of the Foreign Language Anxiety Scale (FLAS) and the studies based on the FLAS by Hewitt and Stephenson (2012), Pérez Castillejo (2018), and Phillips (1992).

KEYWORDS: Oral interviews, Anxiety, Portuguese as an Additional Language (PAL)

\section{RESUMO}

Este estudo de caso analisa o uso da tecnologia de gravação de voz e seus benefícios na preparação para entrevistas orais em cursos de Português como Língua Adicional (PLA). Verifica-se particularmente como o uso de gravações de voz pode diminuir o nível de ansiedade em um grupo de estudantes universitários em um curso de português nos Estados Unidos. Analisa-se o processo de preparação para entrevistas orais com 13 estudantes universitários matriculados em um curso de português de verão em uma universidade de grande porte na Costa Oeste dos Estados Unidos. Este estudo demonstra que as entrevistas orais presencias são beneficiadas pela preparação dos alunos através da utilização de tecnologia. Demonstra-se uma possível correlação entre a preparação dos estudantes e a redução da ansiedade durante as entrevistas orais presenciais. A preparação oferecida a este grupo de alunos também enfatiza a importância de se oferecer uma abordagem sistemática para entrevistas orais e a necessidade de se tratar do nível de ansiedade experienciado por estudantes de línguas durante tais entrevistas. Outros estudos sobre ansiedade dos estudantes são tomados como base teórica para este estudo de caso, especialmente o trabalho seminal de Horwitz, Horwitz e Cope (1986) com a criação da Escala de Ansiedade de Língua Estrangeira (Foreign Language Anxiety Scale - FLAS) e os estudos baseados no FLAS, de Hewitt e Stephenson (2012), Pérez Castillejo (2018) e Phillips (1992).

PALAVRAS-CHAVES: Entrevistas orais, Ansiedade, Português como Língua Adicional (PLA)

\section{Introduction}

Oral interviews are one of the testing components in most Portuguese language courses in the United States. Since the teaching of Portuguese as an Additional Language (PAL) in the U.S. follows, by and large, the communicative approach ${ }^{1}$, the incorporation of oral interviews is seen by most language educators as an important element of any language curriculum in Portuguese Programs. One example of the importance given to oral interviews is the development of a set of guidelines for the Oral Proficiency Interviews (OPI) by the American Council on the Teaching of Foreign Languages (ACTFL).

The 2012 ACTFL Speaking Proficiency Guidelines describe what speakers can do with language in spontaneous and unrehearsed contexts. Proficiency is understood in the ACTFL guidelines as the functional language ability of a speaker, independently of how s/he learned the language. The 2012 ACTFL Proficiency Guidelines provides a specific set of language standards associated with proficiency, describing language ability according to global tasks and functions,

\footnotetext{
1 The Communicative Language Approach, also known as Communicative Language Teaching (CLT) was developed in the 1970s to 1990s as a way to shift the focus from the teaching of grammar from more traditional approaches to language teaching that focuses on the message (communication) (Richards, 2006). We refer to the Communicative Language Approach in this paper as an umbrella term, which includes many types of methodologies and approaches to language teaching focusing on the element of communication (the exchange of unknown information between speakers). Grammatical rules are part of communication but is not seen as the main purpose of it in the CLT approach.
} 


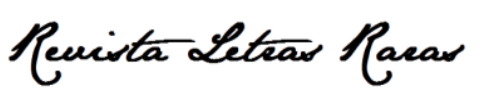

ISSN: 2317-2347 - v. 9, n. 4 (2020)

Todo o conteúdo da RLR está licenciado sob Creative Commons Atribuição 4.0 Internacional

context/content, accuracy, and text type ${ }^{2}$. Following this proficiency framework, the ACTFL guidelines are intended to be used as the standard in the United Sates for language proficiency, with a particular focus on the Oral Proficiency Interview (OPI). The OPI is used to measure the students' level of proficiency when s/he has received a scholarship funded by the U.S. Government, such as the Foreign Language and Area Studies (FLAS), the Boren Fellowship, and the Critical Language Scholarship (CLS). Thus, oral interviews are used to calibrate what students are able to do with language.

The ACTFL 2012 Proficiency Guidelines divide language proficiency in four major levels, namely: novice, intermediate, advanced, and superior. The first three levels have also three sublevels each: low, mid, and high that differentiate the performance of language speakers in one main level describing if the speaker is barely staying at level, having a solid performance at level, or performing most of the time at the next proficiency level. For instance, a language student in Portuguese is generally expected to achieve a novice-high or intermediate-low level of proficiency in most first-year language courses (YADEN; VIANA DA SILVA, 2020). The students' level of language proficiency varies not only because of the quality of the language instruction, but also because of other elements, such as the students' knowledge of another Romance language or the time of exposure to Portuguese in class. In the case of students involved in this study, most of them are in the range of novice-high and intermediate-low proficiency in Portuguese.

If on one side oral interviews are a common practice in PAL programs; on the other, they can also be stressful for many students. In an attempt to reduce student's anxiety, this case study looks at the use of technology as the means to prepare students for oral interviews. It analyzes the learning experience of 13 university students preparing for oral interviews in L2 Portuguese in a first-year Portuguese language course at a major university in the Pacific Northwest of the United States. The hypothesis of this study is that by using an online voice recording resource to complete practice assignments, students experience increased confidence and reduced levels of anxiety during the face-to-face oral interviews. One of the assumptions of this study is that the lack of preparation in class and the levels of students' anxiety can interfere with their performances during oral interviews.

\footnotetext{
2 Global tasks and functions are the tasks that speakers can accomplish as past narrations and detailed descriptions for example; context/content refers to formal or informal situations and the place in which the language is being used (e.g. social gatherings or a university lecturer); accuracy refers to the appropriate use of language structures; and text type relates to the size of speech, as in strings of discrete sentences or in full paragraphs. For a detailed description of the OPI Proficiency Guidelines visit the URL: https://www.actfl.org/center-assessment-research-anddevelopment/actfl-assessments/actfl-postsecondary-assessments/oral-proficiency-interview-opi
} 


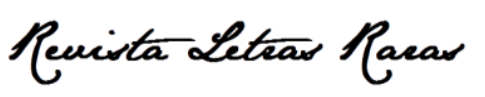

ISSN: $2317-2347$ - v. 9, n. 4 (2020)

Todo o conteúdo da RLR está licenciado sob Creative Commons Atribuição 4.0 Internacional

Given the importance of oral interviews for Portuguese language programs in the United States and elsewhere, it is imperative that more studies in this area are conducted. There is particularly the need for studies focusing on pedagogical practices for oral interviews and their effects on the students' levels of anxiety as research projects on language proficiency and oral interviews with PAL are few and far between.

\section{Literature Review}

Anxiety is described as "a tense unsettling anticipation of a threatening but form-less event; a feeling of uneasy suspense. It is a negative affect (feeling) so closely related to fear that in many circumstances the two terms are used interchangeably" (RACHMAN, 2013, p. 3). Nonetheless, differently than fear, which is a response to an emergency, anxiety can last for days, weeks, or months, and the source of threat for anxiety is elusive (RACHMAN, 2013). Rachman (2013) highlights some similarities between fear and anxiety, which makes it harder to distinguish between the two concepts.

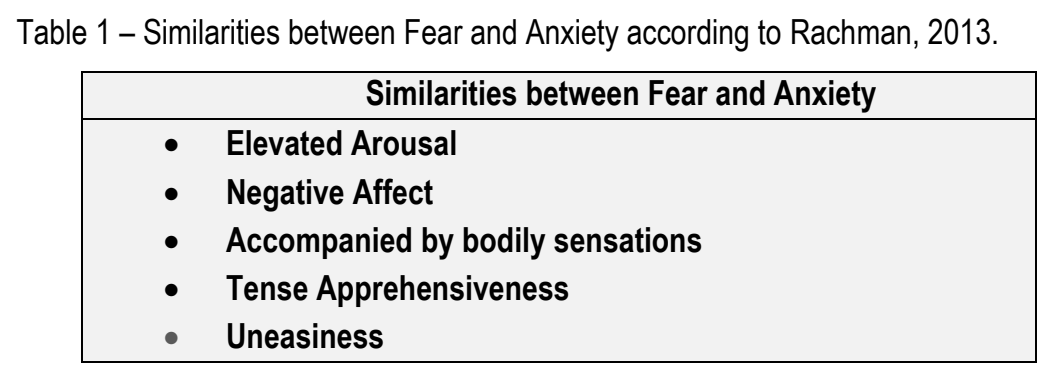

Previous studies in foreign language (FL) education have considered language anxiety as a factor in L2 acquisition. Horwitz, Horwitz and Cope (1986), in their seminal study, propose that foreign language anxiety (FLA) is frequently responsible for student unease in the $\mathrm{L} 2$ classroom. Their study is fundamental to the understanding of anxiety among language students and it inspired the current case study. Horwitz, Horwitz and Cope (1986) offer an instrument to measure anxiety: the Foreign Language Classroom Anxiety Scale (FLCAS). The FLCAS is composed of 33 questions using a Likert scale, ranging from strongly agree to strongly disagree and is designed to measure communication apprehension, test-anxiety, and fear of negative evaluation. The table below shows the first 10 items of the Foreign Language and Classroom Anxiety Scale: 


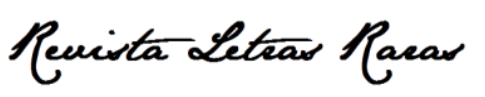

ISSN: 2317-2347 - v. 9, n. 4 (2020)

Todo o conteúdo da RLR está licenciado sob Creative Commons Atribuição 4.0 Internacional

Table 2 - First 10 items of the Foreign Language and Classroom Anxiety Scale (FLCAS)

\begin{tabular}{|l|}
\hline Foreign Language and Classroom Anxiety Scale (FLCAS) by Horwitz et al. (1986) \\
\hline Strongly Agree Agree Neither Agree, nor Disagree Disagree Strongly Disagree \\
\hline 1. I never feel quite sure of myself when I am speaking in my foreign language class. \\
\hline 2. I don't worry about making mistakes in language class. \\
\hline 3. I tremble when I know that I'm going to be called on in language class. \\
\hline 4. It frightens me when I don't understand what the teacher is saying in the foreign language. \\
\hline 5. It wouldn't bother me at all to take more foreign language classes. \\
\hline 6. During language class, I find myself thinking about things that have nothing to do with the course. \\
\hline 7. I keep thinking that the other students are better at languages than I am. \\
\hline 8. I am usually at ease during tests in my language class. \\
\hline 9. I start to panic when I have to speak without preparation in language class. \\
\hline 10. I worry about the consequences of failing my foreign language class. \\
\hline
\end{tabular}

The FLCAS scale, which is partially presented above, was used with a high degree of internal reliability by Horwitz, Horwitz, and Cope (1986) in a pilot study with thirty FL students at the University of Texas. Since then, other researchers have used the FLCAS as their primary instrument to measure anxiety in language learners (Hewitt and Stephenson, 2012; Pérez Castillejo, 2018; Phillips, 1992). Horwitz, Horwitz, and Cope (1986) explain that an anxious foreign language learner displays the same psycho-physiological symptoms, behavior, and subjective feelings characteristic of any type of anxiety. For instance, psycho-physiological symptoms might include sweats, palpitations, and difficulty concentrating. Furthermore, the behavior of anxious FL students is generally affected by testing situations, when anxious students become overconcerned with their performance, tending to over study and suffer from subject feelings of frustration, apprehension, worry, and dread.

Similar findings are highlighted by Huang (2012), in which the FL learner experiences anxiety because of low self-esteem, the sense of competitiveness among classroom peers, and unsuited beliefs that the FL is somewhat unrealistic and frustrating. Students who experience FL anxiety often have unrealistic expectations of themselves and believe that anything less than a perfect performance is a failure. Moreover, as Horwitz (2017) revisited her original work from 1986, she highlights the importance of focusing on the nature of the different language classroom situations, as they dictate the levels of anxiety faced by students. For most students, an oral interview with the instructor raises their level of anxiety.

Hewitt and Stephenson (2012) replicated a study carried out by Phillips in 1992 on the effects of FL anxiety on students' oral performances and attitudes with forty students enrolled in a 


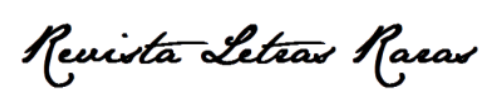

ISSN: 2317-2347 - v. 9. n. 4 (2020)

Todo o conteúdo da RLR está licenciado sob Creative Commons Atribuição 4.0 Internacional

university-level L2 English class using the FLCAS. For the language assessment instrument, Hewitt and Stephenson (2012) used an internationally validated English language proficiency test (Quick Placement Test, 2001), which was not part of Phillips' 1992 groundbreaking research. Both Phillips' study and its replication in 2012 showed a statistically significant correlation between anxiety and oral accomplishment. In the Phillips study (1992), students demonstrating higher levels of anxiety exhibited reduced L2 production; while in Hewitt and Stephenson's study (2012), the relation was the opposite: high-anxious students spoke more in the target language; however, the quality of their L2 was poorer than that of low-anxious students. These contrasting results are attributed by Hewitt and Stephenson to cultural differences between the L1 English-speaking students in Phillips' study and the L1 Spanish-speaking students they investigated.

Another study with the FLCAS by Pérez Castillejo (2018) with thirty-eight L1 speakers of English taking first-year Spanish language classes had similar outcomes to Hewitt and Stephenson' study (2012). Pérez Castillejo (2018) research focused on the levels of anxiety and the correlation with the students' performance during a final oral interview in Spanish. She concluded that students who were more anxious performed poorer on the oral exams, with language breakdowns and more pauses during the speech (including pauses in the middle of sentences) than less anxious students. The study's limitation is that the FLCAS questionnaire was administered in the beginning of the Spanish course and not during the time of the final oral interviews. For that reason, the results of the FLCAS may not correspond to the levels of anxiety that students experienced prior to the oral interviews.

The pressure of foreign language tests and its correlation to higher levels of anxiety was analyzed in depth by Ganschow et al. (1994). They examined the differences in FL anxiety in relation to the L1 oral and written language skills of thirty-six college students identified as highanxious, average-anxious, and low-anxious in introductory Spanish classes at a medium-sized Midwestern university. The results of this study show significant differences in the students' performance in their L2. The high-anxious FL students demonstrated the lowest oral and written skills (phonology and semantics) in their L1. In addition, the high-anxious students had the highest percentage of D's and F's (28\%) when compared to average-anxious (11\%) and low-anxious students (4\%). This indicates that levels of FL anxiety may be related to L1 skills and suggests that while a supportive foreign language classroom is important in fostering strong performance in an L2, there are other variables, such as students' L1 abilities, which language instructors cannot control. 


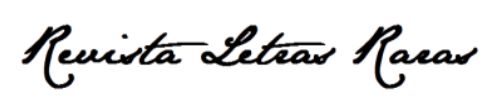

ISSN: 2317-2347 - v. 9, n. 4 (2020)

Todo o conteúdo da RLR está licenciado sob Creative Commons Atribuição 4.0 Internacional

In his seminal work, Krashen (1981) coined the term Affective Filter, describing it as a learning barrier based on emotional effects that are triggered by one's environment. It includes the social pressure to speak in front of peers and the fear of been categorized as unintelligent. Furthermore, Krashen (1981) proposes three main factors that contribute to the strength of the Affective Filter: motivation, self-confidence, and anxiety. Based on Krashen's work, Owen (2012) analyzes the literature on the Affective Filter and proposes the study on the use of a Virtual Environment (VE), avatars, and Animated Pedagogical Agents (APA) to reduce its effects with students of English as a foreign language. Owen argues that Computer Aided Language Learning (CALL) is a way to help reduce the Affective Filter.

If on one hand, the Affective Filter can be important element for understanding students' anxiety during oral interviews; on the other, the relationship between self-confidence, anxiety, and oral performance is also an important aspect. Hyesook and Lee (2004) describe self-confidence as a result of "judgments and evaluations about one's own value and worth" (p. 197). In their 2004 research, they evaluated the relationship between self-confidence, anxiety, and oral performance with one hundred thirty-two Korean college students enrolled in English conversation classes participated in this study. These students answered a questionnaire about their levels of anxiety and self-confidence. In addition, their oral performance was assessed using the International Association of Teachers of English as a Foreign Language's criteria (range, ease of speech, attitude, delivery, and interaction). A correlation analysis of anxiety, confidence, and the students' oral performance showed that the higher the students' L2 confidence, the better their oral performance. Self-confidence was closely related to $L 2$ attitude and interaction, such as communication strategies and social conversation skills. The confident language learners showed several types of confidence: situational, communication, language potential, and language ability. The anxiety of the Korean learners in this study was related to criticism, exams, and oral communication.

The improvement of student confidence and speaking ability was also the focus of a study by Tognozzi and Truong (2009). They proposed the implementation of a voice tool communication product on the web, WIMBA ${ }^{\circledR}$, in traditional language classes in order to improve student confidence and oral production. WIMBA ${ }^{\circledR}$ is a software program that allows students and instructors to communicate through recorded voice messages and voice email. In this quantitative study, the experimental group was composed of sixty college students who used the voice email and oral assessment builder in WIMBA®. A control group of sixty-seven students performed the 


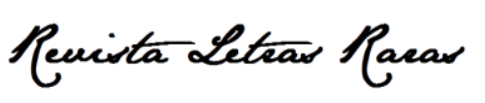

ISSN: 2317-2347 - v. 9. n. 4 (2020)

Todo o conteúdo da RLR está licenciado sob Creative Commons Atribuição 4.0 Internacional

same oral activities in the classroom with the instructor. Both groups performed oral language activities weekly during one semester. The WIMBA® group received feedback on their oral production individually from the teachers through the WIMBA® system while the control group received feedback in the classroom as a group.

Tognozzi and Truong (2009) concluded that students in the WIMBA® group became more confident speaking in class since they had more opportunities to practice their oral production individually and received feedback from the instructor weekly. Their language production was longer and more accurate than the control group. WIMBA®, according to Tognozzi and Truong, "empowered students," made them "actively involved," and "responsible for their own learning" ( $p$. 10). It came, however, with challenges. The researchers pointed out that the process of providing feedback individually to students is time consuming for both instructors and students. In addition, the design of activities for WIMBA $\AA$ and the program itself are costly. Although the technology is sophisticated, it is not without glitches, and there is the need of constant training of students and teachers in how to use the online platform.

Similar results from the research abovementioned were obtained in a study on the implementation of Computer-Mediated Communication (CMC), a real-time, synchronous conversation that takes place via the internet. Satar and Ōzdener (2008) investigated the use of text chat and voice chat with thirty novice-level secondary school learners of English as a foreign language. In their results, they concluded that the English proficiency of both groups (the text-chat and the voice-chat group) increased, while the anxiety level decreased only on the text-chat group. The researchers concluded that $\mathrm{CMC}$ tools can be effective in helping students to gain confidence "by providing them with a safe environment in which to practice and evaluate themselves" (p. 608).

In contrast to the previous research, an empirical study by Baralt and Gurzynki-Weiss (2011) on the level of language learners' anxiety in CMC (text-chat) compared to face-to-face (FTF) interactions, concluded that $\mathrm{CMC}$ was not as effective in reducing anxiety. Their study tested the anxiety levels of twenty-five learners of intermediate Spanish using an anxiety level questionnaire and a task-preference questionnaire. The results reported that the levels of anxiety were comparable across modality (CMC and FTF), contradicting the suggestion that $\mathrm{CMC}$ helps to reduce anxiety. Among the positive features identified in the FTF tasks, students commented that it was natural, engaging, complex, and challenging; among the negative features of FTF, students mentioned that it was fast, nerve wracking, embarrassing, awkward, complex, disappointing, and broken. Baralt and Gurzynki-Weiss (2011) explained that one of the biggest limitations of their study 


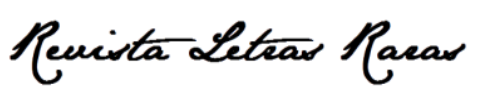

ISSN: 2317-2347 - v. 9. n. 4 (2020)

Todo o conteúdo da RLR está licenciado sob Creative Commons Atribuição 4.0 Internacional

is the fact that students performed the CMC tasks in the same lab with the supervision of their instructor. Perhaps this research would have had a different outcome if students had performed the CMC tasks on their own outside of class. It is very likely that high-anxiety students felt intimidated by having the teacher in the computer lab and by performing the task with the whole class typing in the background. The other limitation is the comparison of writing through the textchat $(\mathrm{CMC})$ with the oral face-to-face interview.

\section{Hypothesis}

By using an online voice recording service to prepare for oral interviews and by receiving feedback in class, students feel more confident and less anxious, having a better performance during face-to-face interviews.

\section{Participants and Class Description}

The participants in this study were 13 students taking an introductory Portuguese class in an intensive six-week summer program at a major university in the Pacific Northwest of the United States. Of the 13 students in the class, 8 of them were heritage speakers of Spanish, and 3 spoke Spanish as second language. Only 2 students were monolingual speakers of English. The class met five times a week for one hour and fifteen minutes and followed a communicative, task-based approach. The oral interviews were intended to reflect the pedagogical approach followed in class.

In terms of the level of speaking proficiency of students in this study, the instructor predicted that students were between the novice and intermediate levels, which is described according to the 2012 ACTFL Speaking Proficiency Guidelines as follows:

Table 3 - Descriptions of the major Novice and Intermediate in the 2012 ACTFL Speaking Proficiency Guidelines

\section{Novice}

Novice-level speakers can communicate short messages on highly predictable, everyday topics that affect them directly. They do so primarily through the use of isolated words and phrases that have been encountered, memorized, and recalled. Novice-level speakers may be difficult to understand even by the most sympathetic interlocutors accustomed to non-native speech.

Intermediate 


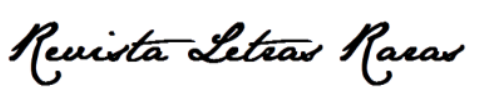

ISSN: 2317-2347 - v. 9, n. 4 (2020)

Todo o conteúdo da RLR está licenciado sob Creative Commons Atribuição 4.0 Internacional

Speakers at the Intermediate level are distinguished primarily by their ability to create with the language when talking about familiar topics related to their daily life. They are able to recombine learned material in order to express personal meaning. Intermediate-level speakers can ask simple questions and can handle a straightforward survival situation. They produce sentence-level language, ranging from discrete sentences to strings of sentences, typically in present time. Intermediate-level speakers are understood by interlocutors who are accustomed to dealing with non-native learners of the language.

Font: https://www.actfl.org/sites/default/files/guidelines/ACTFLProficiencyGuidelines2012.pdf

\section{Case Study and Methodology}

This case study is part of a bigger research conducted for the graduate certificate in college and university teaching. The main goal of this case study is to look at a sample of oral interviews in Portuguese and analyze how the systematic preparation helped students to lower their level of anxiety during the face-to-face oral interviews. Using a qualitative method, the researcher analyzed the voice recorded interviews and the face-to-face interviews and compared his notes and impressions from how students behaved. Students also answered a survey after their final oral interview, in which they reflected on how their preparation helped them to reduce their level of anxiety. The results of the survey were then compared and contrasted to the instructors' notes taken after the face-to-face interviews. This study intends to be mostly informative and its results are preliminary, given the small sample size of oral interviews and the limited number of participants $(\mathrm{N}=13)$.

The oral interviews took place throughout a six-week course and students had three faceto-face oral interviews with the instructor. In preparation for the oral interviews, students completed oral assignments online using a voice recording website: www.vocaroo.com ${ }^{\odot}$. For each assignment, the instructor recorded questions in Portuguese and sent them to students, who then received an email with a link to the instructor's recorded message. After listening to the questions in Portuguese, students recorded their answers and sent them back to the instructor.

Figures 1 and 2 below show the sequence of website windows for the recording. Figure 1 shows the first screen for the $V_{0 c a r o 0^{๑}}$ website. Its simplicity was one of the main reasons why we chose this technological tool.

Figure 1: Opening webpage with record button. 


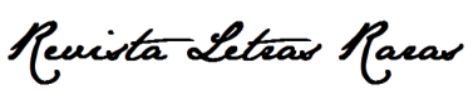

ISSN: 2317-2347 - v. 9, n. 4 (2020)

Todo o conteúdo da RLR está licenciado sob Creative Commons Atribuição 4.0 Internacional

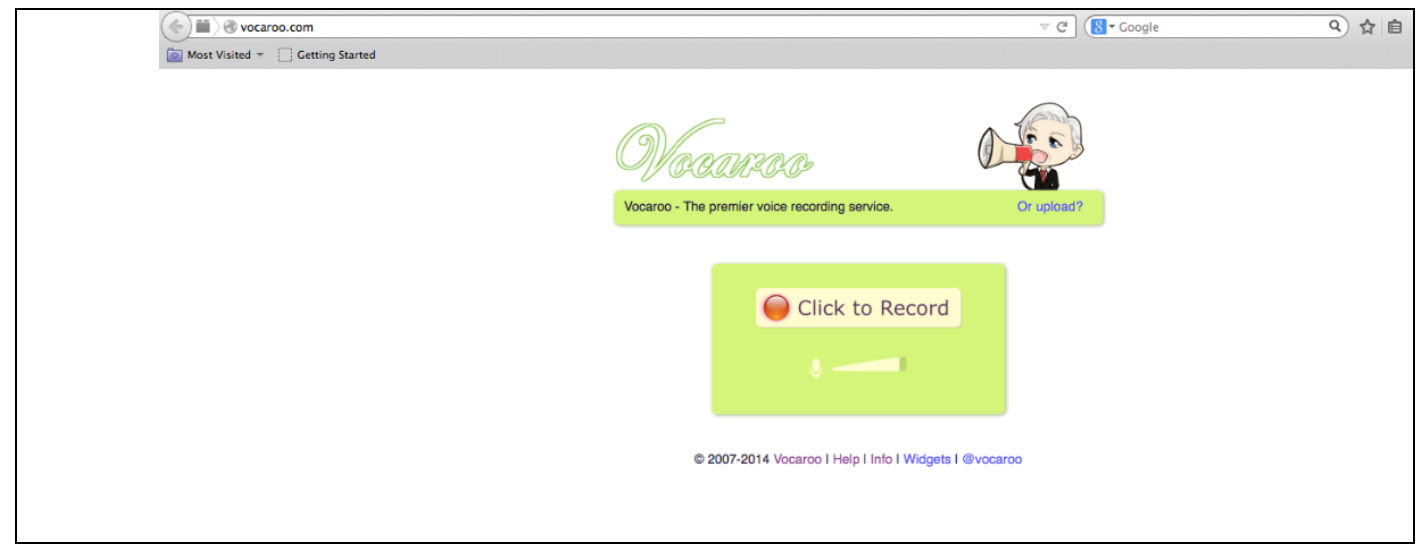

Source: https://vocaroo.com

Figure 1 above is the opening page of the $\operatorname{Vocaroo}^{\odot}$ website, which gives the option to do the voice recording. This is a free website and students can record as many times as needed. Sequentially, Figure 2 shows the computer screen after the voice recording was completed. This technological tool provides students with the option of listening to the recording multiple times. Under Sharing options, students can share their recording via email, Facebook, and Twitter, among other options. It also generates a link for each recording. This is also how students received the directions on the recordings, through a link that the instructor sent to the class. All questions were presented in the same recording and the instructor had a small pause between questions. Students could repeat listen to the recording as many times as needed at home.

Figure 2: Computer screen after the recording is done.

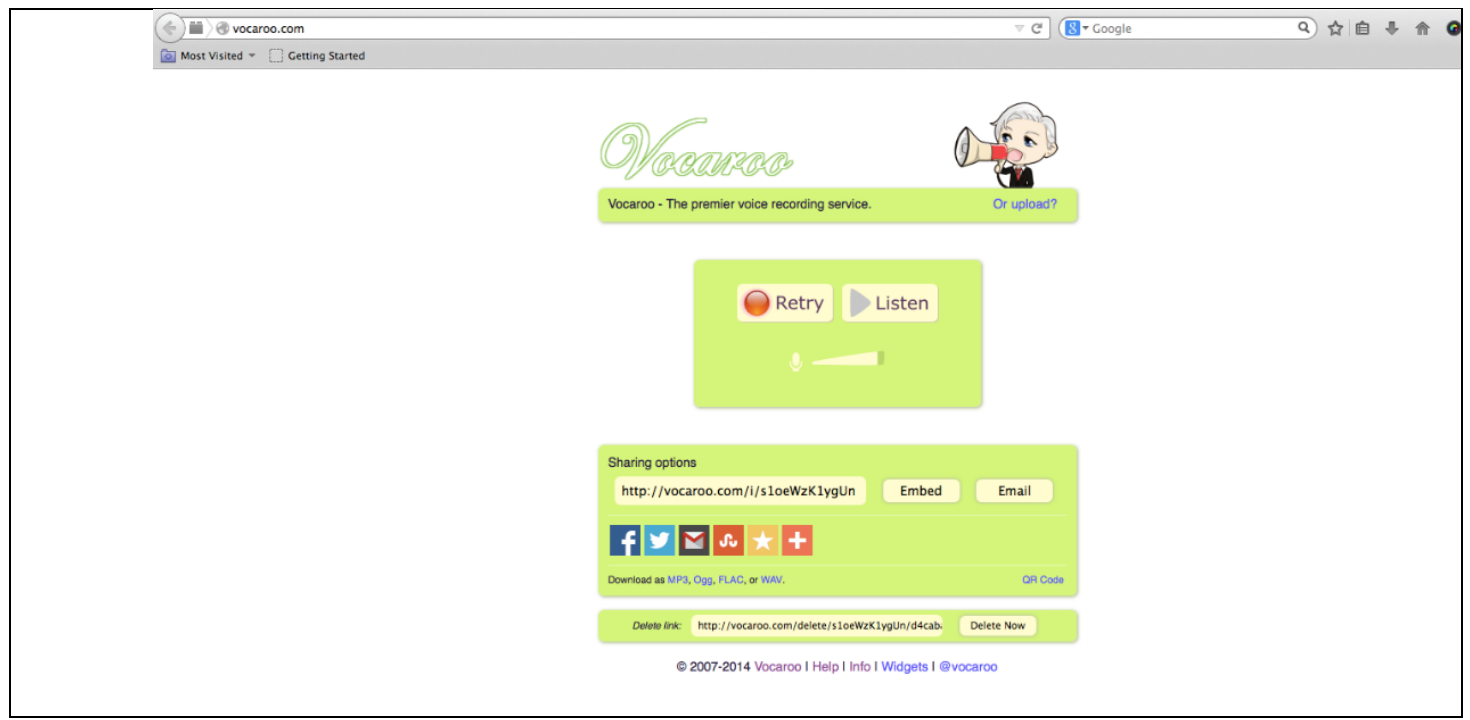

Source: https://vocaroo.com 


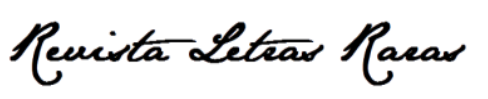

ISSN: 2317-2347 - v. 9, n. 4 (2020)

Todo o conteúdo da RLR está licenciado sob Creative Commons Atribuição 4.0 Internacional

The Vocaroo ${ }^{\odot}$ website allows students to email the recording to several recipients, including themselves. It does not have a limit of recordings and users can control the volume of the recording in the website as well. Upon receiving the recordings, the instructor indicated global errors $^{3}$ in pronunciation, vocabulary, language structures, and any other issue that represented an error pattern or interfered with communication. Students received feedback in class as a group. They had time to ask questions about the assignments and to clarify any misunderstandings. There was also time allowed in class for students to perform their interviews with each other in pairs.

The face-to-face interviews followed the same format as the assignments and were conducted by the instructor during office hours. The instructor recorded the audio from the face-toface interviews using a digital device and did not take any notes during the interviews to avoid distracting students. The oral interviews were adaptive: the type of questions and depth of the conversations changed according to the student's performance during the interview and his/her speaking abilities. In addition, students had the option of recording the audio from the face-to-face interviews with the instructor for future reference. The final grade came from the online assignments and oral interviews combined.

An anonymous opinion survey (see Appendix 1) was given to students at the end of the course to collect their views on the effectiveness of the voice recognition website in helping them to prepare for the oral interviews.

Students had two written exams and a final exam. The oral interviews were worth thirty percent of each of the two exams and the final. The instructor evaluated the voice recording assignments on $\operatorname{Vocaroo}^{\odot}$ and the oral interviews in accordance with a rubric, which included an evaluation of content, comprehensibility, and accuracy.

\section{Voice Recording Assignment Format}

Assignment 1: The first assignment consisted of preparation for a one-on-one interview with the instructor. The questions below were recorded by the instructor and sent to students through the Vocaroo ${ }^{\circledR}$ website. Student had to listen to the questions in Portuguese and record their answers. The same questions were used as the outline for the face-to-face interview, which was conducted individually. The face-to-face interviews lasted on average five minutes.

\footnotetext{
${ }^{3}$ Global errors are the types of errors that hinder communication, preventing the interlocutor from understanding the message, in opposition to local errors, which do not prevent the message from being understood. The terms "global and local errors" were first coined by Brown (2000).
} 


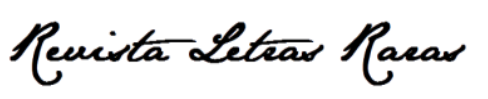

ISSN: 2317-2347 - v. 9. n. 4 (2020)

Todo o conteúdo da RLR está licenciado sob Creative Commons Atribuição 4.0 Internacional

Qual é o seu nome? [What's your name?]

E qual é o seu sobrenome? [What's your last name?]

Como se escreve o seu sobrenome? [How do you spell your last name?]

Onde você mora? [Where do you live?]

O que você estuda? [What do you study?]

Qual é a sua rotina diária? [What's your daily routine?]

O que você gosta de fazer nos fins de semana? [What do you like to do on the weekends?]

Assignment 2: The second assignment consisted in preparation for a role play on ordering food in a restaurant. Students had to answer the questions below through the Vocaroo website. For the face-to-face interview, the instructor acted as the waiter and the role play was done in pairs. In class, students referred to a sample menu in the textbook; and during the role play they had a copy of the same menu. They were also instructed to ask two or three questions each about the menu. This role play lasted in general between five to seven minutes.

Bem vindo ao Restaurante Ronaldinho Gaúcho. O meu nome é Marcelo e vou ser seu garçom hoje.[Welcome to the Restaurant Ronaldinho Gaúcho. My name is Marcelo and I will be your server today.]

Como o senhor vai?/ Como a senhora vai? [How are you, sir/ma'am?]

O senhor gostaria de alguma coisa para beber? [Would you like something to drink, sir?]

O especial de hoje é uma feijoada brasileira com pedaços de laranja e custa 35 reais.

[Today's special is Brazilian bean soup with pieces of orange and it costs 35 reais.]

A senhora gostaria de pedir um prato principal? [Would you like to order the special of the day, ma'am?]

O senhor gostaria de um prato brasileiro ou de um prato português?

[Would you like a Brazilian dish or a Portuguese dish?]

De onde vocês são? [Where are you from?]

De que parte dos Estados Unidos vocês são? [Which part of the United States are you from?]

Como é Santa Bárbara? Eu não conheço. [What's Santa Barbara like? I haven't heard of it.]

Como está a comida? [How is the food?]

A senhora gostaria de uma sobremesa? [Would you like dessert, ma'am?]

Os senhores gostariam de mais alguma coisa? [Would you like anything else?]

Bom, aqui está a conta. O senhor quer pagar com cartão de crédito ou à vista?

[Very well, here is the bill. Would you like to pay by credit card or with cash?]

Obrigado e que tenham um ótimo dia! [Thank you! Have a great day!]

Assignment 3: The third assignment consisted of three parts. In the first part, students had to answer several questions about their hobbies, interests, school life, and daily routine. In the second part, students had to ask between three and four questions to the interviewer. The third part consisted of the following role play: 


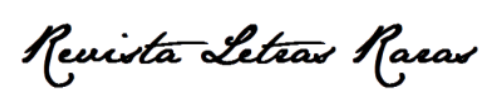

ISSN: 2317-2347 - v. 9, n. 4 (2020)

Todo o conteúdo da RLR está licenciado sob Creative Commons Atribuição 4.0 Internacional

Role Play: You want to rent an apartment. Talk to the building manager and describe what you want. Ask four or five questions to find out everything you need to know (the instructor would then add: "I will be the building manager and you will be the person looking for an apartment.").

For this last assignment, students received the questions through vocaroo.com ${ }^{\odot}$ with the instructor's recording, but they were not required to do their own recording because of time constrains; thus, the students' recording was facultative. Nonetheless, students had to listen to the questions through $\mathrm{Vocaroo}^{\odot}$ in order to prepare for this oral interview. The questions in this section included some of the ones in Assignment 1, as the instructor recycles the content for the class and revisits earlier topics for the final interview. Below are the additional questions for assignment 3.

De onde você vem? [Where do you come from?]

Você pode descrever a sua cidade para mim? [Could you describe your city to me?]

A que horas você acorda? [What time do you wake up?]

Que dias da semana você trabalha? [Which days of the week do you work?]

Você vem de uma família grande ou pequena? Você pode descrever um membro de sua família? Fisicamente e a personalidade também?

[Do you come from a big family or a small one? Could you describe a member of your family, physically in terms of personality as well?]

Você mora em uma casa ou em um apartamento? [Do you live in a house or in an apartment?]

Você pode me descrever o teu apartamento com alguns detalhes para eu ter uma imagem mental do lugar? [Could you describe your apartment with some details so that I can have a mental image of the place?]

Que móveis tem na sala? [Which pieces of furniture do you have in the living room?]

Qual é a cor da sua casa? [What color is your house?]

Você cozinha? O que você come normalmente? [Do you cook? What do you normally eat?]

Você ouve música? Que tipo de música você gosta? [Do you listen to music? Which kind of music do you like?]

The face-to-face interviews for this third assignment lasted on average 15 minutes and were also voice recorded. By having all the voice recorded interviews, the ones from the preparation phase on $V_{0 c a r o 0^{\odot}}$ and the ones from the face-to-face oral interview with the instructor, the researcher was able to contrast and compare the quantity and quality of the language produced by students. The discussion of results shows the contrast and comparisons based on the notes taken by the language instructor on his impressions of the students' behavior during the face-to-face interviews, in addition to the voiced recording of the same interviews and the voice recording of the 


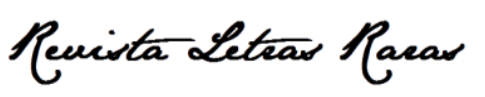

ISSN: 2317-2347 - v. 9, n. 4 (2020)

Todo o conteúdo da RLR está licenciado sob Creative Commons Atribuição 4.0 Internacional

students' preparation for the interviews. Additionally, the self-reflective survey conducted with students was also analyzed and their answers were compared with the notes taken by the instructor.

\section{Discussion of Results}

The results of the opinion survey given students indicate that the voice recognition website was a useful tool in preparing them for the oral interviews. When asked about which oral interview practice helped the most (see Appendix 1), seven students out of thirteen chose both options: the interview recorded on Vocaroo ${ }^{\odot}$ and the face-to-face interview with the instructor. Four students selected the vocaroo.com ${ }^{\odot}$ option as the practice that helped them the most, and two participants chose the interview with the instructor as the most helpful one. In an informal feedback session with the instructor, students commented that the assignment through the recording website had helped them substantially to prepare for the face-to-face interview. Some mentioned that they had recorded themselves several times and were able to improve their performance by repeating the assignment.

In the second question of the survey: "Did the interviews make you nervous or anxious?", the majority of the class, ten out of thirteen students, agreed that there was some level of anxiety in the face-to-face interviews. Only three students claimed not being nervous, although of these three, one wrote "a little bit anxious" in his notes. Among the ten students who reported feeling nervous or anxious, five of them were more nervous with the instructor, while two believe the Vocaroo website made them more nervous and the other three chose both options.

During the face-to-face interviews, the instructor noticed that most students demonstrated some level of nervousness, especially in the first round of interviews. About half of the students were visibly nervous; some were sweating and appeared somewhat distressed. In informal conversations with the instructor prior to and after the interviews, students mentioned that they were not used to doing one-on-one interviews in a foreign language and some had never done an interview with an instructor before.

In general, oral interviews in language departments in the U.S. are conducted in pairs. Around half of the class in this project was composed of freshmen, which is common in introductory language classes at the college level, and some had never taken a language class at the university before. In the second and third interviews, students seemed somewhat more comfortable and used 


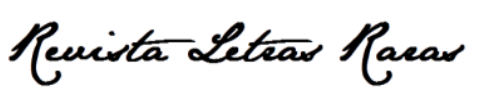

ISSN: 2317-2347 - v. 9, n. 4 (2020)

Todo o conteúdo da RLR está licenciado sob Creative Commons Atribuição 4.0 Internacional

to the idea of doing face-to-face interviews with the instructor. Nonetheless, there was a noticeable level of anxiety and nervousness with most participants.

On question number three of the survey: "Did the recorded interview on vocaroo.com help you with the oral interview with the instructor?", twelve students out of thirteen agreed that the use of the website had been beneficial. The one student who did not agree wrote that he had only used the Vocaroo website after doing the face-to-face interviews. In the comment section, students mentioned that the online assignments encouraged them to listen to their own speech several times. Others said that it made them pay attention to the instructor's questions and to make sure they could understand what was being asked. Some mentioned the challenge of understanding everything asked in the recordings and the need to listen to the questions several times. One student suggested that more class time should be allowed to practice for the oral interviews.

During the feedback section in class, some students realized their misunderstandings of some of the instructor's questions. In addition, students had several questions about the pronunciation of some words and issues with language structures and vocabulary. Since there was a considerable weight on the grades for the oral exams, students wanted to perform well and valued the preparation time given in class. At the same time, it added more pressure to perform well in the oral interviews.

In the last question of the survey, all participants suggested to keep using the website in future assignments. Some wrote that the website forced them to practice for the oral interviews in advance. Others mentioned that $V_{0 c a r o 0^{\odot}}$ was user friendly and that they had no difficulties using it, although one student reported some technical issues in accessing the site with his laptop. The overall response, nevertheless, was positive.

\section{Conclusion}

By using voice recording technology in this introductory Portuguese class, students spent more time in preparing for oral interviews than they normally would have and their level of anxiety seems to be reduced. Since the students' recordings for Assignments 1 and 2 were part of their final grade, most students did their assignments on time and in the order prescribed: first the recordings on vocaroo.com ${ }^{\odot}$ and then the face-to-face interviews. The recordings done by students also showed the instructor the strengths and weaknesses of their oral production. For the most part, the instructor was able to address global errors that interfered with communication in class 


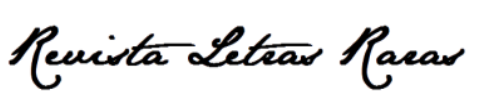

ISSN: 2317-2347 - v. 9, n. 4 (2020)

Todo o conteúdo da RLR está licenciado sob Creative Commons Atribuição 4.0 Internacional

prior to the face-to-face interviews. Although the use of an online voice recording program cannot substitute face-to-face interaction, it may help in preparing students for real-life situations. It is also a good tool for instructors to identify what they should focus on in order to help students enhance their FL learning experience.

Given that this study was conducted before the Covid-19 pandemic, we did not deal with the current anxiety of meeting in person. We predict that if we would conduct this research during the Covid-19 pandemic, many of the participants would encourage the voice recording option and also opt to synchronous interviews through an electronic platform as Zoom ${ }^{\odot}$ of Google Groups ${ }^{\odot}$, instead of meeting in person. We would predict that level of anxiety would also be higher.

In regards to the students' level of anxiety in the oral assignments in this study, most students seemed to experience a reduction in anxiety as the course progressed and as they engaged in the several steps of the preparation for the oral interviews. While the instructor observed that in the final oral interviews some students still demonstrated anxiety and nervousness, in general they seemed more comfortable than they were in the first oral interview.

Further research including a larger number of participants is necessary in order to identify the impact of the online voice-recording assignments in reducing levels of FL anxiety. In addition, we suggest the use of an instrument to measure FL language anxiety, such as the Foreign Language Classroom Anxiety Scale (FLCAS). The future study should involve at least two classes, one as the control group and the other as the experimental group. In addition, we suggest the use of two measurement instruments: a qualitative approach (interviews) and a quantitative approach (FLAS). We would also suggest the inclusion of a background survey at the beginning of the course, including questions about the students' anxiety in oral interviews and their previous FL learning experiences. A statistic test, such as a MANOVA, is also recommended in order to analyze the possible variables involved in the study, such as the time dedicated by students for the preparation for the oral interviews, the time constraints of the interview, and other possible factors that might influence the student's anxiety level during the oral interview, such as learning disabilities and individuals predisposed to high levels of anxiety.

Even though the oral interviews in this preliminary research project were part of a test, students learned during the preparation process by having opportunities to practice their speaking abilities. The students' preparation and the feedback provided in class increased their confidence and reflected positively in the outcome of their face-to-face interviews in Portuguese. Previous 


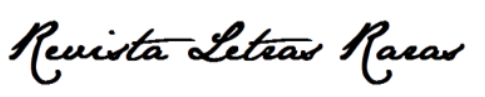

ISSN: 2317-2347 - v. 9, n. 4 (2020)

Todo o conteúdo da RLR está licenciado sob Creative Commons Atribuição 4.0 Internacional

research that focused on student confidence have come to similar conclusions supporting these findings (TOGNOZZI AND TRUONG, 2009; HYESOOK AND LEE, 2004).

In addition, the focus given to the oral interviews in this course matched its communicative and task-based language approach. Future research on the application of voice recording websites as tools to prepare students for oral interviews is necessary in order to further investigate the hypothesis of the current research.

As a final remark, the decision to include the website vocaroo.com@ arose primarily because of the site's simplicity and the fact that it was free to use. During the time of this research, vocaroo worked well in all assignments. After the end of this project, however, some of the data were compromised, as some of the recordings had been erased from the website and could not be retrieved. Thus, the study has its own limitations in regards to the data not recovered and the liability of this type of resource. In future projects, we recommend other voice recognition services. Furthermore, this study is not meant as an endorsement of vocaroo.com@; rather, it is meant to support the use of online voice recording platforms as technological tools. It is up to the discretion of language teachers and program coordinators to decide which online resource to use.

\section{Appendix 1}

Survey about Oral Interviews in Portuguese

1 - Which oral interview practice helped the most?

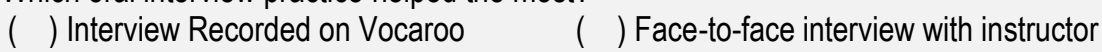

2 - Did the interviews make you nervous or anxious? Please, elaborate your answer considering the two types of interviews (recorded interview on vocaroo.com and the face-to-face interview with the instructor.

3 - Did the recorded interview on vocaroo.com help you with the oral interview with the instructor?

4 - Would you suggest that we keep using the website Vocaroo in preparation for face-to-face oral interviews in future assignments?

\section{References}

BARALT, M.; GURZYNSKI-WEISS, L. Comparing learners' state of anxiety during task-based interaction in computer-mediated and face-to-face communication. Language Teaching Research. Thousand Oaks, CA: Sage, v. 15, n. 2, 2011, p. 201-229. 


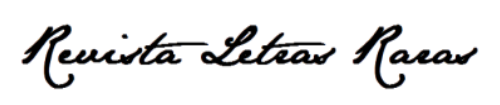

ISSN: 2317-2347 - v. 9. n. 4 (2020)

Todo o conteúdo da RLR está licenciado sob Creative Commons Atribuição 4.0 Internacional

BROWN, H. D. Principles of Language Learning and Teaching. New York: Longman, 2000.

GANSCHOW, L.; SPARKS R.; ANDERSON R.; JAVORSHY, J. Differences in language performance among high-, average-, and low-anxious college foreign language learners. The Modern Language Journal. New Jersey, NY: Wiley, v. 78, n. 1, 1994, p. 41-55.

HEWITT, E.; STEPHENSON, J. Foreign language anxiety and oral performance: a replication of Phillips's MLJ study. The Modern Language Journal. New Jersey, NY: Wiley v. 96, n. 2, 2012, 170 189.

HORWITZ E., HORWITZ M.; COPE J. Foreign language classroom anxiety. Modern Language Journal. New Jersey, NY: Wiley, v. 70, n. 2, 1986, p. 125-132.

HORWITZ, E. K. On the misreading of Horwitz, Horwitz, and Cope (1986) and the need to balance anxiety research and the experiences of anxious language learners. In: Gkonou, C., Daubney, M., \& Dewaele, J. M. (Eds.), New insights into language anxiety: Theory, research and educational implications. Bristol, UK: Multilingual Matters, 2017, p. 31-50.

HUANG, Q. Study of correlation of foreign language anxiety and English reading. Theory and Practice in Language Studies, v. 2, n. 7, 2012, p. 1520-1525.

KRASHEN, S. Second language acquisition and second language learning. Oxford, UK: Pergamon Press, 1981.

LEACH, 0 . The future of language learning: Using technology to eliminate the affective filter (Unpublished paper). Worcester, Massachusetts: Worcester Polytechnic Institute, 2012.

PARK, H.; LEE, A. L2 Learners' anxiety, self-confidence and oral performance. Semantic Scholar. Kunsan: Kunsan National University, 2006.

PÉREZ CASTILLEJO, S. The role of foreign language anxiety on L2 utterance fluency during a final exam. Language Testing, v. 36. n. 3, 2019, p. 327-345.

PHILLIPS, E. The effects of language anxiety on students' oral test performance and attitudes. Modern Language Journal, New Jersey, NY: Wiley, v. 76, n. 1, 1992, p. 14-26.

RACHMAN, S. Anxiety. Clinical Psychology, a Modular Course. London: Psychology Press, 2013.

RICHARDS, J. Communicative Language Teaching Today. Cambridge: Cambridge University Press, 2006.

SATAR, H.; ŌZDENER, M. The effects of synchronous CMC on speaking proficiency and anxiety: Text Versus Voice Chat. Modern Language Journal. New Jersey, NY: Wiley, v. 92, n. 4, 2008, p. 595-613.

TOGNOZZI, E.; TRUONG, H. Proficiency and assessment using WIMBA Voice Technology. Italica: American Association of Teachers of Italian. Fayetteville: University of Arkansas, v. 86, n. 1, 2009, p. 1-23.

YADEN, B.; VIANA DA SILVA, E. O papel da proficiência em programas de português. Hispania. v. 103, n. 4, 2020: p. 461-74. 